\begin{tabular}{|c|c|c|c|c|c|c|}
\hline \multirow{4}{*}{ Impact Factor: } & ISRA (India) & $=3.117$ & SIS (USA) & $=0.912$ & ICV (Poland) & $=6.630$ \\
\hline & ISI (Dubai, UAI & $=0.829$ & РИНЦ (Russia) & $=0.156$ & PIF (India) & $=1.940$ \\
\hline & GIF (Australia) & $=0.564$ & ESJI (KZ) & $=8.716$ & IBI (India) & $=4.260$ \\
\hline & JIF & $=1.500$ & SJIF (Morocco & $=5.667$ & OAJI (USA) & $=0.350$ \\
\hline
\end{tabular}

\section{SOI: $1.1 /$ TAS $\quad$ DOI: $10.15863 /$ TAS International Scientific Journal Theoretical \& Applied Science}

p-ISSN: 2308-4944 (print) e-ISSN: 2409-0085 (online)

Year: 2019 Issue: $06 \quad$ Volume: 74

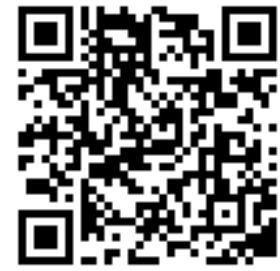

Published: $26.06 .2019 \quad$ http://T-Science.org
QR - Issue

QR - Article

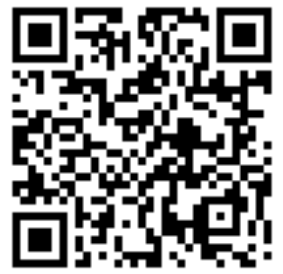

A.M. Radjabova

International Islamic Academy of Uzbekistan Lecturer,

+998909010153

aziza_dip@mail.ru

\title{
EMERGENCE AND SOME STAGES OF THE EVOLUTION OF GENDER PHENOMENON
}

Abstract: The focus in the article is given to the analysis of the emergence and evolution of gender phenomenon in the human-beings history. It comparatively analyzes different interpretations of relationships between men and women at different times, and stages of development. It explains the importance of equality, which provides protection of equal rights for men and women.

Key words: gender, gender studies, feminism, sustainable development, development indicators, social status.

Language: English

Citation: Radjabova, A. M. (2019). Emergence and some stages of the evolution of gender phenomenon. ISJ Theoretical \& Applied Science, 06 (74), 512-515.

Soi: http://s-o-i.org/1.1/TAS-06-74-58 Doi: crossef https://dx.doi.org/10.15863/TAS.2019.06.74.58

\section{Introduction.}

Women's social activity has become one of the most important issues in human development. The social and political status of women is determined by such factors as political consciousness and the breadth of thoughts, participation in social, economic and political processes in the society. Meanwhile, the issues of equality between men and women have always been relevant in the process of political decision-making. the study of the historical and evolutionary development of gender issues revealed that the views on relationships between men and women have undergone various developmental stages at different times in the sense that the status of women was based on several factors.

\section{Main part.}

In particular, the fact that women in the past have lower status than men is defined not only by a political factor, but also by a physiological factor. From the first quarter of the 20th century, this issue had its own scientific language, and began to be referred to in the scientific literature as "gender problem", "gender equality" or any other similar terms. The main focus of these terms is concentrated on considering equal rights of men and women in social life. However, today their attitude toward this vital issue is radically changing.

One of the leading gender researchers, Joan Scott, praises the following statement on gender issues in his article "Gender: The Useful Category of Historical Analysis": "gender is not only a matter of opening new pages of history for women in the process of analyzing history of humanity, but also of creating a new history itself"[1-2]. Early gender research (Sherry Ortner, Wendy Cealey Harrison, Spelman, Collins, Laurel Furumoto and Elizabeth Scarborough) has focused on sociology and psychology, focusing mainly on the comparison of anthropological characteristics of men and women, similar and distinctive features, emotional experiences and other similarities in personalities. However, the modern meaning of the gender phenomenon is wider than ever, whereas many non-governmental organizations are working to address gender issues. The main purpose of this paper is to clarify the historical stages of the formation of the modern "gender" phenomenon.

The first look at gender is fundamentally different from that of today's integrated interpretation. In particular, the views of Western feminist women, promoting gender equality, served as a driving force of these studies. The idea of feminists refers to the guarantee of gender equality in decision-making processes, politically, economically and socially. It also implies full and effective participation of women in all areas of professional activities - ranging from ordinary to executive positions, and ensuring equal opportunities for them. The following are examples of 


\begin{tabular}{|c|c|c|c|c|c|c|}
\hline \multirow{4}{*}{ Impact Factor: } & ISRA (India) & $=3.117$ & SIS (USA) & $=0.912$ & ICV (Poland) & $=6.630$ \\
\hline & ISI (Dubai, UAI & $=0.829$ & РИНЦ (Russia & $=0.156$ & PIF (India) & $=1.940$ \\
\hline & GIF (Australia) & $=0.564$ & ESJI (KZ) & $=8.716$ & IBI (India) & $=4.260$ \\
\hline & JIF & $=1.500$ & SJIF (Morocco & $=5.667$ & OAJI (USA) & $=0.350$ \\
\hline
\end{tabular}

how the equality between men and women can be realized in practice.

In many cases, including in antiquity, women were subjected to social norms and to degrading and social status. According to ancient scholars, women status were comparable with slaves status [3]. According to an ancient antiquity philosophy, a man's domination over a woman is based on the principle of status-quo given to men [4]. The relationship between man and woman was the same as the relationship between the ruler and the slave [5]. Plato points out this in a somewhat relaxed form in his book The Republican: "The relationship between man and woman in society is built on the basis of sovereignty and self-reliance"[6]. Plato, unlike Aristotle, does not regard women as slaves, but as a citizen who is governed by men. Women's vulnerability tells men to be able to rule them. It is worth mentioning that the main reasons why women were left out of politics at that time were their ignorance.

In the XVI-XVII centuries the western scientific impetus is focused on assessing the rights of women and men and their social equality, with all the characteristics of the two sexes. As a result of the research, the phisical, psychological and emotional well-being of the male gender has further strengthened the status of women. Studies on political leadership were mostly carried out by men, with very little information about women's case [7]. Therefore, it is a bit more difficult to get clear facts. Nevertheless, it is possible to observe active participation of women in public affairs at certain times. In particular, royal family members, as the younger generations of the throne, were the only members of the royal family who were considered to be widows of the deceased king. Particularly, active participation of women in the governance of the British, French, Castile and Aragones countries in the Carolingian and Merovingian dynasties, as well as the active participation of women in governance.

By the 18th century, scientists concluded that men and women are one cohesive system and fill each other. However, women still had no natural and political rights. The revolutionary views of the 19th century have made radical changes. New class opponents of the old bourgeois system have begun to propagate the idea that each individual has the right to contribute to the development of the society. This idea will later become a motto for feminist movements. Women who initially acted as representatives of the working class, later began to fight for their political rights. Feminist ideas have had a strong impact on the economic, social, political and technological development of states.

At the beginning of the 20th century, the world's unemployment rate reached its peak. In this situation, women were the most vulnerable part of the society. Therefore, the main task of the international organizations established between the WWII was the implementation of economic and social reforms aimed at ensuring employment. The Society for Psychological Study of Social Problems (SPSII) [8], established in 1936, is among them. The role of the organization in promoting women's political and economic status, in particular their leadership potential, has led to the realization of today's reforms related to women's status.

"Women's problems", more precisely, the weak involvement of women in society has become a major topic of sociology in the mid-20th century. The main problem of women is that they have an inadequate capacity for biodiversity and cultivation in senior positions [9]. Naturally, this claim was rejected by women themselves. It can be said that the number of feminist women has increased. As a result, the movement began to gather representatives from various sectors. This, in turn, has led to the study of women's role and status in society not only as a practical player, but also as a scientific one. Thus, in the world of science there was a scientific direction called "gender studies" or "women's studies".

The fact that the United States was founded in 1966 by the Women's National Organization was a practical and scientific impetus. The spectrum of research carried out in the West has been enriched with a new trend of the Germanic science. This kind of work began to be the subject of small research topic in the early years of major and empirical research centers. At the same time, this sector has become one of the main directions of a number of international organizations, non-governmental and non-profit organizations. From the end of the 20th century, faculties and higher education establishments specializing in this issue began to emerge. Undergraduate, Graduate, Ph.D. degrees and research centers were functioning in partnership with the International Gender Studies Center (Social Sciences Division) at the International Department of Social Sciences [10]. Moreover, UNDP, UN Women, Human Rights, FAO, ECOSOS, UNICEF, World Bank (WB), UNAIDS, as well as the Organization for Economic Cooperation and Development and the Organization for Security and Cooperation in Europe started their gender studies. Among the goals of these organizations are to promote gender equality, empower women, monitor and analyze women's rights and interests worldwide, develop and implement relevant laws and programs in these areas. These tasks are becoming increasingly important.

Another important aspect is that the United Nations and several other international organizations have developed a program to establish sectoral programs to reflect the realities in this area. The main goal is to make a fair assessment of progress and shortcomings in the area of gender equality and to develop new priorities. On September 25, 2015, the UN Sustainable Development Goals were adopted. This strategy provides a shared blueprint for peace and 


\begin{tabular}{|c|c|c|c|c|c|c|}
\hline \multirow{4}{*}{ Impact Factor: } & ISRA (India) & $=3.117$ & SIS (USA) & $=0.912$ & ICV (Poland) & $=6.630$ \\
\hline & ISI (Dubai, UAI & $=0.829$ & РИНЦ (Russia & $=0.156$ & PIF (India) & $=1.940$ \\
\hline & GIF (Australia) & $=0.564$ & ESJI (KZ) & $=8.716$ & IBI (India) & $=4.260$ \\
\hline & JIF & $=1.500$ & SJIF (Morocco & $=5.667$ & OAJI (USA) & $=0.350$ \\
\hline
\end{tabular}

prosperity for people and the planet, now and into the future and also covers areas such as gender equality and women's rights and their empowerment [11]. Sustainable development goals are to further extend the achievements that have so far been reached, including the elimination of discrimination against women and girls around the world. In addition, the UN has developed a Human Development Indicator that evaluates progress in various areas of the country for 1990-2017, in which gender-specific parameters are also envisaged. According to the UN's Human Development Index, which has been published since 1990, this indicator for women is 0.705 and for men 0.749 [12]. The analysis of these indicators shows that the vital aspects of women's role are significantly less important. This situation is based on a number of interconnected factors. Particularly, women's scientific potential, professional skills, work ability, political participation in the society, social security, social, economic and political rights, economic development, welfare and some other factors.

It should be stressed that international attention to gender issues is constantly growing. This can be seen in a number of concrete facts. In particular, the annual International Economic Forum is preparing a special report that identifies gender indicators and covers 144 countries. The report is based on four directions of indexation - indicators of economic activity in the country, achievements in the education system, healthcare and expansion of political capacity [13].

The role of women and men in social life, ensuring their equitable distribution of natural, social, economic, political rights and freedoms, opportunities and responsibilities is one of the priorities facing democratic countries based on a free market economy. Women's empowerment is an important factor in addressing many of the challenges. As the world experience shows, such an approach will serve to ensure sustainable growth rates in the country, a high potential of additional labor, a decrease in unemployment rates, the eradication of social inequalities, a decline in social security, and strengthening social stability and other vital issues.

\section{Conclusion.}

In today's globalized world, the members of the "gentle sex" systematically strengthen their social status by taking advantage of their abilities and potential in socio-economic and political life, as well as by utilizing the privileges and opportunities they create. Their aspiration to work equally with men in all areas is becoming increasingly evident. In the conditions of Uzbekistan, this reality is especially noticeable. In particular, this conclusion confirms the fact that women participate in entrepreneurship and have their own business and property. All this is a good result of the privileges, conditions and high attention created to women.

\section{References:}

1. Scott, J. W. (1986, Dec.). Gender: A useful Category of Historical analysis. The American Historical Review, Vol. 91, No. 5, pp. 10531075.

2. Gordon, A. D., Buhle, M. J., \& Dye, N. S. (1976). The problem of Women's History." In Berenice Carroll, ed., Liberating Women's History (Urbana . III., 1976), 89.

3. (1980). Aristotle. Nicomachean Ethics. Translated and with an introduction by David Ross. Revised by J.L. Ackrill and J.O. Urmson. (Eds.). Oxford: Oxford University Press.

4. Parker, H. N. (n.d.). Aristotle's Unanswered Questions:Women and Slaves in Politics 1252a1260b/

5. (n.d.). Aristotel on Women and slaves.

6. (n.d.). Edward Clayton Aristotle: Politics, Chapter 12, 1245b12, Retrieved 2019, from https://www.iep.utm.edu/aris-pol/
7. Borghini, A. (n.d.). Plato and Aristotle on Women: Selected Quotas. Retrieved 2019, from https://www.thoughtco.com/plato-aristotle-onwomen-selected-quotes-2670553

8. Meade, T. A., \& Wiesner - Hanks, M.E. (2004). A companion to gender History. P26 http://www.blackwellpublishing.com

9. Kesler, U. R. (1986). Handbook of the Psychology of women and Gender. Stagner.

10. Boring, E. G. (1951). The woman problem. American Psychologst, 5, pp.679-682. Women's Studies at Flinders University, Adelaide, South Australia, MSt in Women's Studies proceed to doctoral degrees at Oxford and at other universities, Harvard University, Boston College, Brandeis University, Tufts UniversityTufts University, Northeastern University, Boston University, Simmons College, MIT Program in Women's and Gender Studies (WGS), Massachusetts Institute of 


\begin{tabular}{|c|c|c|c|c|c|c|}
\hline \multirow{4}{*}{ Impact Factor: } & ISRA (India) & $=3.117$ & SIS (USA) & $=0.912$ & ICV (Poland) & $=6.630$ \\
\hline & ISI (Dubai, UAE & $=0.829$ & РИНЦ (Russia & $=0.156$ & PIF (India) & $=1.940$ \\
\hline & GIF (Australia) & $=0.564$ & ESJI (KZ) & $=8.716$ & IBI (India) & $=4.260$ \\
\hline & JIF & $=1.500$ & SJIF (Morocco & $=5.667$ & OAJI (USA) & $=0.350$ \\
\hline
\end{tabular}

Technology, Centre for Women's Studies (CWS), The Department of Women's Studies and Feminist Research at Western University, the University of Michigan Women's Studies Department https://www.ox.ac.uk/admissions/graduate/cour ses/mst-womens-

studies?wssl=1\#,http://wgs.mit.edu,

http://www.flinders.edu.au/sabs/ssps/womensstudies/,

https://www.york.ac.uk/study/postgraduate- taught/courses/ma-womens-studies/, https://www.uwo.ca/womens/about_/index.html , https://lsa.umich.edu/women

11. (n.d.). The sustainable development goals 2015 2030. Retrieved 2019, from una-gp.org

12. (2018). Human development indices and Indicators, Statistical Update 2018 by UNDP.

13. (2017). World Economic Forum, The global gender gap report 2017. Retrieved 2019, from http://weforum.org 